\title{
Pengaruh Kemampuan dan Motivasi Terhadap Kinerja Anggota DPRD Kota Banjarmasin
}

\author{
Nurhikmah \\ Dosen Sekolah Tinggi Ilmu Manajemen Indonesia (STIMI) Banjarmasin
}

Abstract

The good performance of the legislature in this autonomy era is a necessity and necessity so that the institution can carry out its duties, authority and rights accountably, be more responsive and reliable. Good performance is certainly influenced by ability, leadership and work motivation and discipline of the board members themselves. On the basis of these reasons the authors are interested in discussing and knowing how the Effect of Ability and Motivation on the Performance of Banjarmasin City DPRD Members. This study aims to be able to describe the ability, work motivation and performance, then analyze the influence of work ability and motivation on the performance of Banjarmasin City DPRD Members then analyze the influence of the dominant variables between work ability and motivation dominant influence on the performance of Banjarmasin City DPRD Members.

The analytical tool used in this study is to use used validity and reliability testing tools for the data, reliability testing was carried out by Cronbach Alpha test. To find out the influence between Ability (X1), Motivation (X2) and Performance (Y), simultaneous regression analysis methods are used as follows: Ability Test Results (X1), Motivation (X2) on Performance (Y) simultaneously on DPRD Members Banjarmasin. The analysis used is Linear Regression and tested using a distribution table.

Based on the results of the research results, it can be stated that simultaneously it is known that for Ability $t$ count $=2.914 *>\mathrm{t}(45 ; 0.05)=1.679$ is significant and for Motivation $\mathrm{t}$ count $=0.944 \mathrm{~ns}<\mathrm{t}(45 ; 0.05)=1.679$ which means that work ability has a significant effect on the performance of Banjarmasin City DPRD members, while non-significant work motivation means ability and motivation can affect performance even though there are motivational variables that cannot influence the performance of Banjarmasin City DPRD members. Work ability is the variable that has the dominant influence on the performance of Banjarmasin City DPRD members, because based on the results of the ability test, motivation on performance simultaneously on members of Banjarmasin City DPRD, it is known that the ability variable has the most dominant influence, compared to the motivation variable.

Keywords: Ability, Motivation, Performance

Abstrak

Kinerja lembaga legislatif yang baik di era otonomi ini merupakan suatu kebutuhan dan keharusan agar lembaga tersebut dapat melaksanakan tugas, wewenang dan hak-haknya secara akuntabel, lebih responsif dan reliable. Kinerja yang baik sudah barang tentu dipengaruhi oleh kemampuan, kepemimpinan dan motivasi kerja serta kedisiplinan anggota dewan sendiri. Atas dasar alasan tersebut penulis tertarik untuk membahas dan mengetahui bagaimana Pengaruh Kemampuan dan Motivasi terhadap Kinerja Anggota DPRD Kota Banjarmasin. Penelilitian ini bertujuan untuk dapat mendeskripsikan kemampuan, motivasi kerja dan kinerja, kemudian menganalisis pengaruh kemampuan dan motivasi kerja terhadap kinerja Anggota DPRD Kota Banjarmasin selanjutnya menganalisis pengaruh variabel yang dominan antara kemampuan dan motivasi kerja berpengaruh dominan terhadap kinerja Anggota DPRD Kota Banjarmasin.

Adapun alat analisis yang digunakan dalam penelitian ini adalah menggunakan digunakan alat uji validitas dan reabilitas terhadap data, uji reliabilitas dilakukan dengan uji Alpha Cronbach. Untuk mengetahui adanya pengaruh antara Kemampuan $\left(\mathrm{X}_{1}\right)$, Motivasi $\left(\mathrm{X}_{2}\right)$ dan Kinerja $(\mathrm{Y})$, digunakan metode analisis regresi secara simultan sebagai berikut : Hasil Uji Kemampuan $\left(\mathrm{X}_{1}\right)$, Motivasi $\left(\mathrm{X}_{2}\right)$ terhadap Kinerja $(\mathrm{Y})$ secara simultan pada Anggota DPRD Banjarmasin. Analisis yang digunakan adalah Regresi Linear dan di uji dengan menggunakan tabel distribusi.

Berdasarkan hasil penelitian hasil penelitian ini dapat dikemukakan bahwa secara simultan diketahui bahwa untuk Kemampuan $\mathrm{t}_{\text {hitung }}=2,914 *>\mathrm{t}_{(45 ; 0.05)}=1.679$ adalah signifikan dan untuk Motivasi $\mathrm{t}_{\text {hitung }}=0,944^{\mathrm{ns}}<$ $\mathrm{t}_{(45 ; 0.05)}=1.679$ yang berarti bahwa kemampuan kerja berpengaruh secara signifikan terhadap kinerja anggota DPRD Kota Banjarmasin, sedangkan motivasi kerja non signifikan, artinya kemampuan dan motivasi dapat mempengaruhi kinerja walaupun terdapat variabel motivasi yang tidak dapat mempengaruhi kinerja anggota DPRD Kota Banjarmasin. Kemampuan kerja merupakan variabel yang berpengaruh dominan terhadap kinerja anggota DPRD Kota Banjarmasin, karena berdasarkan hasil uji kemampuan, motivasi terhadap kinerja secara simultan pada anggota DPRD Kota Banjarmasin, diketahui bahwa variabel kemampuan mempunyai pengaruh paling dominan, dibandingkan dengan variabel motivasi.

Kata kunci: Kemampuan, Motivasi, Kinerja

Page $\mid 51$ 


\section{PENDAHULUAN}

Kompetensi kekuasaan di lembaga legislatif telah dilaksanakan pada tanggal 9 April 2014. Melalui persiapan yang dilakukan secara besarbesaran, bahkan menjadi sebuah pesta demokrasi yang membutuhkan energi yang sangat besar dan dirangkai dalam ide-ide yang menjadi tujuan, kemudian melalui visi dan misi yang sempurna, kampanye resmi dan terselubung yang dirancang jauh hari melalui Undang-undang Politik.

DPRD Kota Banjarmasin periode 2014-2019 sendiri yang terdiri dari 45 orang telah dilantik secara resmi oleh Ketua Pengadilan Negeri Banjarmasin tanggal 8 September 2014. Anggota DPRD Kota Banjarmasin yang telah terpilih masih didominasi oleh wajah-wajah lama, sementara berdasarkan cacatan kinerja DPRD Kota Banjarmasin periode sebelumnya yaitu 2009-2014, terdapat beberapa hal yang cukup baik dari DPRD Kota Banjarmasin dalam menjalankan fungsinya. Untuk fungsi legislasi adalah telah menghasilkan sebanyak 182 Rancangan Peraturan Daerah (Raperda). 101 buah Raperda diantaranya merupakan usulan Pemerintah Kota Banjarmasin dan 81 sisanya merupakan usulan DPRD Kota Banjarmasin melalui legislasi DPRD Kota Banjarmasin. Raperda tersebut menghasilkan 153 Perda (Peraturan Daerah).

Tabel 1

Jumlah Peraturan Daerah DPRD Kota Banjarmasin

Tahun 2009-2014

\begin{tabular}{cc}
\hline Tahun & Perda \\
\hline 2009 & 24 \\
2010 & 25 \\
2011 & 28 \\
2012 & 33 \\
2013 & 20 \\
2014 & 23 \\
\hline Jumlah & 153
\end{tabular}

Sumber :www.radarbanjarmasin.co.id, diakses pada tanggal 9 Sept' 2014.

Berdasarkan data ini maka DPRD Kota Banjarmasin termasuk sangat produktif dan memiliki kinerja yang cukup memuaskan dari segi kualitas, karena mampu bekerja sesuai perencanaan yang ada meskipun dari segi kualitas Peraturan Daerah yang dihasilkan masih dipertanyakan, apakah mampu menjawab segala persoalan yang ada dihadapi masyarakat Kota Banjarmasin.

Untuk merancang kebijakan yang sejalan dengan aspirasi masyarakat, anggota DPRD Kota Banjarmasin harus mempunyai sensitifitas terhadap persoalan, kepentigan dan aspirasi dari masyarakat, maka pembuat kebijakan yakni anggota DPRD Kota Banjarmasin dituntut memiliki kinerja yang baik sebagaimana yang diatur dalam Pasal 9 Keputusan DPRD Nomor 10/Kpts/DPRD/2010 dan berdasarkan PP Nomor 16 Tahun 2010 tentang Pedoman Penyusunan Pegaturan Tata Tertib DPRD mempunyai beberapa fungsi : (1) Legislasi, berkaitan dengan pembentukan paraturan daerah; (2) Anggaran, kewenangan dalam hal anggaran daerah (APBD); (3) Pengawasan, kewenangan mengontrol pelaksanaan Perda dan peraturan lain serta kebijakan pemerintah daerah.

Berdasarkan cacatan prestasi yang telah ditoreh oleh DPRD Kota Banjarmasin terutama terkait kemampuan dalam menghasilkan Peraturan Daerah (Perda) yang boleh dikatakan sangat produktif mulai tahun 2009 sampai dengan tahun 2014. Kemudian berdasarkan data yang ada bahwa para legislator terpilih pada periode tahun 20142019 ini adalah sebagian besar merupakan wajah lama kemungkinan kinerjanya tidak akan jauh berbeda. Kinerja DPRD yang baik sudah barang tentu dipengaruhi oleh kemampuan, kepemimpinan dan motivasi kerja serta kedisiplinan anggota dewan itu sendiri.Atas dasar alasan tersebut maka penulis tertarik untuk membahas dan mengetahui, bagaimana Pengaruh Kemampuan dan Motivasi Kerja terhadap Kinerja Anggota DPRD Kota Banjarmasin.

Sebagaimana yang diuraikan di atas, maka peneliti merasa perlu untuk mengkaji dan menelaah lebih lanjut tentang bagaimana deskripsi kemampuan, motivasi kerja dan kinerja? Kemudian bagaimana pengaruh kemampuan dan motivasi kerja terhadap kinerja Anggota DPRD Kota Banjarmasin ?dan manakah diantara kemampuan dan motivasi kerja yang berpengaruh dominan terhadap kinerja Anggota DPRD Kota Banjarmasin ?

\section{METODE PENELITIAN}

\section{Desain Penelitian}

Penelitian ini menggunakan pendekatan kuantitatif kausal komparatif dengan menggunakan metode survey untuk menjelaskan hubungan kausalitas antara variabel kemampuan dan motivasi kerja terhadap kinerja anggota DPRD. Dalam penelitian ini variabel-variabel yang diteliti tidak dikendalikan.

Objek penelitiannya adalah Anggota DPRD.Teknik analisis yang digunakan adalah analisis jalur (path analysis). Analisis ini akan digunakan dalam menguji besarnya kontribusi yang ditunjukkan oleh koefisien jalur pada setiap diagram jalur dari hubungan kausal antar variabel kemampuan $\left(\mathrm{X}_{1}\right)$, motivasi kerja $\left(\mathrm{X}_{2}\right)$, terhadap kinerja Anggota DPRD (Y).

\section{Populasi dan Teknik Pengambilan Sampel}

Populasi (N) dalam penelitian ini adalah anggota DPRD Kota Banjarmasin yang berjumlah 45 (empat puluh lima) orang dan oleh karena populasi kecil maka diambil seluruhnya sebagai 
sampel metode yang digunakan adalah metode sensus.

\section{Pengukuran}

Penelitian ini terdiri dari variabel bebas, yaitu kemampuan $\left(\mathrm{X}_{1}\right)$ dan Motivasi $\operatorname{Kerja}\left(\mathrm{X}_{2}\right)$; sedangkan variabel tergantung adalah Kinerja anggota DPRD (Y).Variabel Kemampuan $\left(\mathrm{X}_{1}\right)$ secara operasional diukur dengan ; Pengetahuan dan Keterampilan. Sedangkan variabel Motivasi Kerja $\left(\mathrm{X}_{2}\right)$ yang ditunjukkan dengan indicator antara lain adalah motif, harapan dan insentif . Dan untuk Variabel Kinerja Anggota DPRD (Y) indikatornya meliputi : (a) Akuntabilitas : Akuntabilitas berkaitan dengan kemampuan anggota dewan dalam bertindak sesuai dengan aspirasi masyarakat dan kepentingan untuk terpilih kembali pada pemilu berikutnya. Anggota dewan dikatakan akuntabel apabila para pemilih dapat melihat bahwa para politisi tersebut melakukan tindakan sesuai dengan kepentingan mereka dan menyetujui tindakan pemerintah secara wajar. Sehingga para politisi tersebut akan terpilih kembali pada pemilu berikutnya. (b) Responsivitas, berkaitan dengan kemampuan anggota legislatif dalam mentransformasikan berbagai aspirasi masyarakat dalam kebijakan publik. Seorang anggota legislatif disebut responsif apabila mereka mengadopsi berbagai kebijakan yang telah disignalkan masyarakat sebagai isyarat preferensi mereka seperti opini publik, hasil polling, berbagai bentuk perilaku politik langsung seperti demonstrasi, unjuk rasa, menulis surat pembaca dalam suatu surat kabar, dan semacamnya. (c) Reliabilitas berkaitan dengan kemampuan anggota legislatif dalam mentransformasikan berbagai issu dan program yang mereka tawarkan pada saat kampanye ke dalam suatu kebijakan publik. Anggota dewan dikatakan kinerjanya baik apabila mereka mampu memenuhi setidaknya dua kriteria yaitu sebagai berikut : (1) Kebijakan-kebijakan yang dibuat atau diperjuangkan sesuai dengan platform politik (issu dan program) yang mereka tawarkan pada saat kampanye pemilu; (2) Upaya pencapaian platform politik ini semata-mata dimaksudkan untuk mencapai kesepakatan sesuatu yang terbaik bagi konstituennya.

\section{Teknik Pengumpulan Data}

Data yang akan diambil dalam penelitian ini adalah berupa data primer sedangkan metode pengumpulan data dilakukan dengan cara menyebarkan kuesioner kepada 45 (empat puluh lima) responden. Disamping itu, dilakukan pula wawancara langsung dengan pimpinan DPRD Kota Banjarmasin yang dianggap mengetahui dengan pasti tentang hal-hal yang terkait dengan permasalahan yang akan dibahas dalam penelitian ini.

\section{Analisis Data}

Teknik analisis data dilakukan dengan beberapa tahapan, sebagai berikut :

1. Melakukan analisis deskriptif tentang variasi dengan menampilkan tabel-tabel frekuensi, ratarata. Pada bagian ini, dideskripsikan tentang variasi responden dalam merespons masingmasing butir pertanyaan atau pernyataan yang disampaikan kepadanya.

2. Menentukan model matematis yang mencerminkan hubungan sebab akibat antara variabel tergantung dengan variabel bebas. Model ini diperlukan untuk melakukan prediksi terhadap perubahan variabel tergantung yang diakibatkan oleh perubahan variabel bebas. Dalam penelitian ini, digunakan model regresi linear berganda yang dirumuskan sebagai berikut :

$\mathrm{Y}=\mathrm{a}+\mathrm{b} 1 \mathrm{X} 1+\mathrm{b} 2 \mathrm{X} 2+\mathrm{e}$

$\mathrm{Y}=\mathrm{a}+\mathrm{b}_{1} \mathrm{X}_{1}+\mathrm{b}_{2} \mathrm{X}_{2}+\mathrm{l}_{\mathrm{r}}$

$\mathrm{Y}=$ Kinerja

$\mathrm{X}_{1} \quad$ Kemampuan

$\mathrm{X}_{2} \quad=$ Motivasi kerja

$\mathrm{e} \quad=$ Variabel error

Dalam perhitungan pengolahan data, data penelitian mempergunakan alat bantu yang berupa program aplikasi computer yaitu SPSS versi 19

\section{HASIL PENELITIAN}

Data pada penelitian ini merupakan data primer yang diperoleh dengan cara menyebarkan kuisioner pada anggota DPRD Kota Banjarmasin. Populasi dalam penelitian ini ialah seluruh anggota DPRD Kota Banjarmasin, yang menjadi responden ialah Ketua, Sekretaris, dan anggota DPRD dari fraksi dan komisi di kota Banjarmasin, karena mereka terlibat secara langsung.Kuisioner sebanyak 45 eksemplar yang terdiri dari : $\quad$ Fraksi Gerindra dan Partai Bulan Bintang 4 eksemplar. Fraksi Partai Golongan Karya7 eksemplar.Fraksi PDIP 5 eksemplar, Fraksi PKB5 eksemplar, Fraksi PPP5 eksemplar, Fraksi PKS4 eksemplar, raksi PAN4 eksemplar, Fraksi Demokrat5 eksemplar, Fraksi Hanura dan Nasdem4 eksemplar.

Berikut ini akan diuraikan gambaran secara umum responden penelitian yang diklasifikasikan berdasarkan jenis kelamin, usia, masa kerja serta tingkat pendidikan.Karakteristik responden berdasarkan tingkat pendidikannya diketahui sebanyak 8 orang $(17,77 \%)$ menempuh pendidikan sampai dengan jenjang Pasca Sarjana atau S2, sebanyak 29 orang $(64,44 \%)$ menempuh pendidikan sampai dengan jenjang Sarjana atau S1, sebanyak 8 orang $(17,77 \%)$ menempuh pendidikan sampai dengan SMA sederajat.Berdasarkan data di atas tingkat pendidikan responden sudah cukup memadai sehingga dalam rangka pemberian jawaban butir-butir kuisioner dianggap mengerti dan bisa menginterpretasikan dengan baik butir- 
butir pertanyaan dalam kuisioner secara benar (sesuai harapan) dan tidak menemui kesulitan dalam menafsirkannya serta kecil kemungkinan memiliki interpretasi ganda terhadap pernyataan/pertanyaan yang diberikan.

Karakteristik responden berdasarkan jenis kelaminnya diketahui sebanyak 36 orang $(80 \%)$ adalah laki-laki dan sebanyak 9 orang $(20 \%)$ adalah perempuan.Dilihat dari umur/usia responden maka sebanyak 3 orang $(6,66 \%)$, sebanyak 5 orang $(11,11 \%)$, sebanyak 16 orang $(35,55 \%)$, dan sebanyak 12 orang $(26,66 \%)$ serta sebanyak 9 orang $(20 \%)$. Sehingga berdasarkan usia responden berada di usia/umur produktif dari 26 tahun hingga 50 tahun, yang secara umum telah memiliki kematangan psikologis dan mapan secara ekonomi, sehingga dapat berperan secara maksimal dalam melaksanakan tugas sebagai seorang legislator.

Karakteristik responden berdasarkan lama menjabat, diketahui sebanyak 25 orang $(55,55 \%)$ menjabat 5 tahun pertama (satu periode) dan sebanyak 20 orang $(44,44 \%)$ menjabat 10 tahun (dua periode). Dalam hal lama menjabat sebagai legislator dianggap sudah cukup berpengalaman karena hampir setengahnya adalah wajah-wajah lama yang telah menjabat satu periode sebelumnya dan sekarang menjalani periode 5 tahun kedua, sehingga dianggap memiliki pengetahuan dan keterampilan yang memadai dalam menunjang tugasnya sebagai seorang legislator daerah.

Deskripsi variabel penelitian dilakukan dengan mengacu pada grand mean yang merupakan harga mean per item. Cara yang dilakukan adalah dengan membuat interval kelas dengan jumlah kelas sebanyak 5 (lima), kemudian masing-masing kelas ditafsirkan dengan menggunakan kalimat kualitatif sangat setuju, setuju, netral, tidak setuju dan sangat tidak setuju.

Dengan menggunakan skala likert (Sugiyono : 2001) rentang skor yaitu 1 sampai dengan 5, sehingga dapat dihitung kelas sebagai berikut :

\section{Lebar Interval $=\underline{\text { Nilai tertinggi }- \text { Nilai Terendah }}$ Jumlah Kelas$$
=(5-1) / 5
$$$$
=0,8
$$

Langkah berikutnya adalah dengan membuat interval kelas distribusi frekuensi dan interval kelas tersebut ditafsirkan dengan menggunakan kalimat kualitatif yaitu :

$\begin{array}{ll}1,0-1,8= & \text { Sangat rendah } \\ 1,8-2,6= & \text { Rendah } \\ 2,6-3,4= & \text { Sedang } \\ 3,4-4,2= & \text { Tinggi } \\ 4,2-5,0= & \text { Sangat Tinggi }\end{array}$

Sebagai dasar untuk mengelompokkan hasil persentase tanggapan dari masing-masing responden dapat ditentukan berdasarkan nilai interval dengan formulasi sebagai berikut : $\begin{gathered}\text { Interval Kelas } \\ \text { Jumlah Kelas }\end{gathered}=\underline{100 \%}=\underline{100 \%}=20 \%$

Dengan nilai interval tersebut, maka deskripsi hasil presentase jawaban responden atas persepsi jawaban yang diberikan dikategorikan sebagai berikut :

0,00-19,99 : $\quad$ Tidak

setuju/sangat sedikit/sangat kecil

20,00-39,99 : $\quad$ Kurang

setuju/sedikit/sebagian kecil

40,00 - 59,99 : Cukup

setuju/Cukup banyak/Cukup besar

60,00- 79,99

Setuju/Banyak/Sebagian besar

$80,00-100,00 \quad$ : $\quad$ Sangat setuju/Sangat Banyak/Sangat Besar

Selanjutnya pada bab ini akan dijelaskan tanggapan responden tentang kemampuan, motivasi dan kinerja melalui distribusi frekuensi dan nilai rata-rata yang diketahui pada tabel sebagai berikut

a. Hasil Deskripsi Variabel Kemampuan $\left(\mathrm{X}_{1}\right)$

Kemampuan merupakan kapasitas anggota DPRD Kota Banjarmasin dalam melaksanakan tugasnya, yang diukur berdasarkan indikator seperti : indikator pengetahuan, indikator keterampilan bahwa responden yang termuat ke dalam 18 (delapan belas) item sebagai berikut :Berdasarkan akumulasi jawaban responden tentang variabel kemampuan diperoleh skor rata-rata indicator pengetahuan sebagai variabel kemampuan sebesar 4,40. Hal ini menunjukkan bahwa anggota DPRD Kota Banjarmasin memiliki pengetahuan yang baik sehingga memiliki kapasitas yang baik pula dalam menjalankan tugasnya.Namun demikian memang ada hal yang perlu ditingkatkan terutama kemampuan mengatasi atau menyelesaikan berbagai masalah dilapangan yang cukup sulit, sehingga masih terus menambah pengetahuan dan bersikap terbuka untuk menerima masukan dalam rangka meningkatkan kemampuan sebagai seorang legislator, untuk membantu mengatasi berbagai permasalahan kemasyarakatan di lapangan.Berdasarkan akumulasi jawaban responden tentang nilai rata-rata indicator keterampilan sebagai variabel kemampuan kerja diperoleh skor rata-rata jawaban sebesar 4,40. Hal ini menunjukkan bahwa kemampuan kerja anggota DPRD Kota Banjarmasin dapat dikategorikan baik. Tetapi masih ada beberapa hal yang menjadi catatan terkait kemampuan anggota DPRD Kota Banjarmasin dalam mencapai target karena tuntutan volume pekerjaan, sebagai wakil rakyat.

b. Hasil Deskripsi Variabel Motivasi $\left(\mathrm{X}_{2}\right)$

Motivasi dalam penelitian ini merupakan kondisi yang berpengaruh membangkitkan, mengarahkan dan memelihara perilaku yang 
berhubungan dengan lingkungan kerja anggota DPRD Kota Banjarmasin dalam menjalankan pekerjaan sebagai legislator, yang diukur dengan menggunakan 3 (tiga) indicator yaitu kebutuhan berprestasi (need for achievement), kebutuhan fisik (psychological need), kebutuhan rasa aman (safety need). Adapun hasil tanggapan responden terhadap butir pertanyaan variabel motivasi:

Berdasarkan akumulasi jawaban responden tentang variabel motivasi diperoleh skor ratarata variabel motivasi sebesar 4,00. Hal ini menunjukkan bahwa motivasi yang diberikan kepada legislator DPRD Kota Banjarmasin dapat dikategorikan sudah baik.Hanya beberapa hal oleh sebagian legislator dianggap tidak menjadi factor motivasinya dalam hal initerkait dengan masalah penghargaan atas prestasi kerja yang baik dan motif untuk menjadi seorang legislator. Kemudian berdasarkan akumulasi jawaban responden tentang indicator harapan dalam variabel motivasi diperoleh skor rata-rata variabel motivasi sebesar 4,23. Hal ini menunjukkan bahwa motivasi yang diberikan oleh anggota DPRD Kota Banjarmasin sudah sangat baik.Namun ketika para legislator menghadapi persoalan pribadi maka kiranya pimpinan partai/dewan perlu memberikan nasihat dan rasa simpatik yang cukup.Selanjutnya akumulasi jawaban responden tentang indicator insentif pada variabel motivasi diperoleh skor rata-rata variabel sebesar 3,83. Hal ini menunjukkan bahwa motivasi yang diberikan kepada para anggota DPRD Kota Banjarmasin terkait insentif sudah baik, tetapi dianggap tidak menjadi factor penentu motivasinya terutama masalah imbalan yang pantas, masalah pribadi dan kenaikan pangkat.

\section{c. Hasil Deskripsi Variabel Kinerja (Y)}

Kinerja merupakan hasil kerja yang dicapai oleh seseorang atau pun suatu organisasi sesuai dengan wewenang dan tanggung jawabnya sebagai gambaran mengenai tentang besar kecilnya hasil yang dicapai dari suatu kegiatan baik dilihat secara kualitas maupun kuantitas sesuai visi dan misi.Berdasarkan akumulasi jawaban responden tentang variabel kinerja anggota DPRD Kota Banjarmasin diperoleh skor jawaban sebesar 4,83 (indicator akuntabilitas), 4,39 (indicator responsivitas), 4, 66 (indicator reliability). Ini berarti bahwa kinerja anggota DPRD Kota Banjarmasin dikategorikan sangat baik.Meskipun masih ada beberapa hal yang perlu dioptimalkan ketangguhan dalam bekerja dan bersedia mengadopsi berbagai kebijakan melalui opini public atau pun unjuk rasa.

\section{PEMBAHASAN}

Berdasarkan hasil penelitian diketahui bahwa nilai rata-rata kemampuan anggota DPRD Kota Banjarmasin dapat dikategorikan sangat baik.Kemampuan anggota DPRD Kota Banjarmasin dicerminkan dari indicator pengetahuan dan indicator keterampilan. Meskipun kemampuan kerja anggota DPRD Kota Banjarmasin sudah baik, namun ada beberapa hal yang perlu segera mendapat perhatian organisasi agar kinerjanya menjadi baik yaitu pembekalan pengetahuan bagaimana mengatasi masalah dilapangan yang cukup sulit sehingga anggota DPRD Kota Banjarmasin dituntut untuk lebih bersikap terbuka untuk menerima masukan, sehingga mampu mencapai target kerja karena tuntutan volume pekerjaan yang tinggi, sebagai seorang legislator yang menuntut pengetahuan yang memadai dan tentunya disempurnakan dengan keterampilan/skill yang cukup memadai.

Motivasi anggota DPRD Kota Banjarmasin dilihat dari motivasi yang ditunjukkan dengan indikator motif, indikator harapan, dan indikator insentif.Meskipun motivasi yang diberikan kepada anggota DPRD Kota Banjarmasin dapat dikategorikan sudah baik, tetapi ada beberapa hal menurut hasil penelitian dan pengolahan data yang diperoleh menunjukkan bahwa responden menganggap motivasi terhadap penghargaan atas prestasi kerja yang baik belum menjadi factor yang dapat mendorong anggota dewan untuk bekerja lebih baik sebagai seorang legislator. Selain itu ketika seorang legislator menghadapi persoalan pribadi maka perlu mendapat perhatian dari pimpinan partai/dewan untuk memberi nasihat, advokasi dan rasa simpatik sehingga seorang legislator merasa memiliki harapan akan adanya dukungan terhadap segala keputusan yang diambil dalam menyelesaikan masalahnya. Selanjutnya yang tidak kalah menarik dan perlu diperhatikan ke depannya adalah adanya imbalan yang pantas dan kenaikan pangkat bagi para legislator yang memiliki prestasi kerja baik oleh pimpinan partai maupun dewan sendiri, sebagai motivasi kerja anggota DPRD Kota Banjarmasin dalam rangka meningkatkan kinerja DPRD Kota Banjarmasin.

Kinerja anggota DPRD Kota Banjarmasin dikategorikan baik sekali.Hal ini dilihat berdasarkan beberapa indicator yaitu akuntabilitas, responsivitas dan reliability. Meskipun demikian masih ada beberapa hal yang perlu dioptimalkan terkait dengan ketangguhan dalam bekerja dan bersedia mengadopsi berbagai kebijakan melalui opini publik atau pun unjuk rasa, ini berkaitan erat dengan kemampuan legislator menyelesaikan masalah dilapangan yang cukup sulit yang masih perlu mendapat perhatian, dimana hal ini perlu mendapat perhatian untuk dilakukan evaluasi agar kinerja DPRD Kota Banjarmasin lebih baik lagi. 
Ada beberapa hal yang perlu diperhatikan antara lain fasilitas kerja yang memadai, perlunya sarana penelitian dan kepustakaan, tenaga sekretariat, dan spesialisasi komisi - komisi di DPRD. Kinerja lembaga legislatif dalam sistem politik tentunya merupakan cermin terlaksananya kehidupan bernegara, mengingat tupoksi yang diemban oleh lembaga legislatif daerah saat ini sangat besar, namun ada 2 faktor yang dapat mempengaruhi kinerja seseorang yaitu :

1. Faktor individual meliputi ; sikap, sifat-sifat kepribadian, sifat fisik, keinginan atau motivasinya, umur, jenis kelamin, pendidikan, pengalaman kerja, latar belakang budaya dan lain sebagainya.

2. Faktor sosial dan organisasi, meliputi kebijaksanaan organisasi, jenis latihan dan pengawasan, sistem upah dan lingkungan sosial.

Dari analisis hasil penelitian diketahui bahwa kemampuan dan motivasi kerja anggota DPRD Kota Banjarmasin secara parsial berpengaruh signifikan terhadap kinerja anggota DPRD Kota Banjarmasin, yang ditunjukkan dari nilai uji $\mathrm{t}$ diketahui bahwa $\mathrm{t}_{\text {hitung }}=6,907>\mathrm{t}_{(45 ; 0.05)}=1.679$ adalah sangat signifikan (**). Artinya Kemampuan dapat mempengaruhi Kinerja dan dapat diketahui terdapat hubungan yang cukup kuat (di mana koefisien korelasi atau $\mathrm{R}=0,725$ ) antara Kemampuanterhadap Kinerja. Artinya jika kemampuan tersebut diperbanyak $1 \%$ saja, maka kinerja tersebut akan meningkat sebesar $0,225 \%$.Selanjutnya jika dilihat dari data koefisien diterminasi $\left(\mathrm{R}^{2}\right)=0,526$ artinya terdapat sebanyak 52,6\% kemampuanmempengaruhi Kinerja tersebut, dan sisanya $47,4 \%$ Kinerja tersebut dipengaruhi oleh faktor lain. Kemudian berdasarkan uji $\mathrm{t}$ diketahui bahwa $\mathrm{t}_{\text {hitung }}=5,835>\mathrm{t}_{(45 ; 0.05)}=1.679$ adalah sangat signifikan (**), Artinya Motivasi dapat mempengaruhi Kinerja dan dapat diketahui terdapat hubungan yang cukup kuat (di mana koefisien korelasi atau $\mathrm{R}=0,665)$ antara Motivasiterhadap Kinerja. Artinya jika Motivasi tersebut diperbanyak $1 \%$ saja, maka kinerja tersebut akan meningkat sebesar $0,268 \%$.Selanjutnya jika dilihat dari data koefisien diterminasi $\left(\mathrm{R}^{2}\right)=0,442$ artinya terdapat sebanyak $44,2 \%$, motivasimempengaruhi kinerja tersebut, dan sisanya $52.6 \%$ Kinerja tersebut dipengaruhi oleh faktor lain.

Berdasarkan uji t secara simultan diketahui bahwa untuk Kemampuan $\mathrm{t}_{\text {hitung }}=2,914 *>\mathrm{t}_{(45 ; 0.05)}$ $=1.679$ adalah signifikan dan untuk Motivasi $t_{\text {hitung }}$ $=0,944^{\mathrm{ns}}<\mathrm{t}_{(45 ; 0.05)}=1.679$. Artinya secara simultan Kemampuan dan Motivasi dapat mempengaruhi Kinerja walaupun terdapat variabel Motivasi yang tidak dapat mempengaruhi Kinerja, dapat disimpulkan pula bahwa variabel kemampuan mempunyai pengaruh yang paling dominan, hal ini ditunjukkan oleh nilai $\mathrm{t}_{\text {hitung }}=2,914^{*}$ ( signifikan) dibandingkan dengan variabel motivasi $\mathrm{t}_{\text {hitung }}=$ $0,944^{\text {ns }}$.

Hal ini mengindikasikan bahwa antara kemampuan dan motivasi anggota DPRD masingmasing memiliki peran penting dalam upaya meningkatkan kinerja anggota DPRD.Kemampuan anggota DPRD Kota Banjarmasin dalam penelitian ini memberikan pengaruh yang signifikan terhadap kinerjanya.Hal tersebut menunjukkan bahwa kemampuan kerja menentukan kinerja anggota DPRD. Seorang legislator yang memiliki kemampuan kerja yang baik, akan memudahkannya dalam melaksanakan pekerjaan yang tentunya juga akan berdampak positif terhadap kinerja anggota DPRD yang bersangkutan. Namun sebaliknya jika kemampuan kerja anggota DPRD kurang baik, maka anggota DPRD tersebut akan banyak menemui kendala-kendala atau hambatan ketika melaksanakan pekerjaannya, sehingga anggota DPRD tersebut akan sulit untuk mencapai kinerja yang maksimal.

Dari hasil penelitian diketahui bahwa kemampuan kerja merupakan variabel yang berpengaruh dominan terhadap kinerja anggota DPRD Kota Banjarmasin dibandingkan dengan variabel motivasi, yang ditunjukkan dari nilai koefisien beta yang standarisasi variabel kemampuan kerja sebesar 0,725 lebih besar dibandingkan nilai koefisien beta yang distandarisasi variabel motivasi sebesar 0,665. Hal ini menegaskan bahwa kemampuan kerja merupakan dimensi paling penting dalam upaya meningkatkan kinerja anggota DPRD Kota Banjarmasin. Kondisi ini dapat dipahami karena sebaik apapun kemampuan kerja legislator tanpa adanya motivasi yang didukung lingkungan kerja yang kondusif, maka tidak akan dapat bekerja dengan baik. Oleh karena itu sebaliknya DPRD Kota Banjarmasin dalam pengelolaan sumber daya manusianya bisa mengorientasikan kemampuan kerja anggota DPRD terlebih dahulu yang kemudian juga perlu mendukung motivasi anggota DPRD, serta lingkungannya.Sementara itu motivasi merupakan daya dorong yang mampu menggerakkan anggota DPRD untuk giat dan memiliki semangat dalam bekerja sehingga berdampak pada peningkatan kinerja legialator.Tetapi jika motivasi rendah tentu akan membawa dampak tidak baik terhadap kinerja anggota dewan, karena anggota dewan cenderung malas bekerja, merasa tertekan dalam melaksanakan pekerjaan, sehingga anggota dewan merasa tertekan dalam melaksanakan tugasnya sebagai wakil rakyat, dan cenderung banyak melakukan kesalahan atau pun pelanggaran. Motivasi anggota DPRD Kota Banjarmasin dalam penelitian ini diukur dari beberapa indicator antara lain : motif, harapan dan insentif.

Hal ini menunjukkan bahwa keterkaitan antara kemampuan kerja yang tinggi dan motivasi yang 
tepat akan memberikan kontribusi positif terhadap peningkatan kinerja anggota DPRD Kota Banjarmasin. Hal ini diperkuat dengan hasil analisis yang menunjukkan bahwa variabel kemampuan dan motivasi kerja memiliki kontribusi positif dalam menentukan kinerja anggota DPRD, sedangkan lainnya ditentukan oleh variabel lain yang tidak diteliti, misalnya : kepemimpinan, karakteristik pekerjaan, karakteristik individu, komitmen dan lain sebagainya dapat menjadi pertimbangan DPRD Kota Banjarmasin dalam mengoptimalkan kinerja para anggota DPRD Kota Banjarmasin.

Temuan penting dalam penelitian ini adalah bahwa kemampuan anggota DPRD Kota Banjarmasin mempunyai pengaruh yang sangat baik terhadap kinerja anggota DPRD Kota Banjarmasin, terutama terkait indikator pengetahuan dimana para anggota dewan memiliki kemampuan beradaptasi terhadap dengan cepat melalui rekan kerja sehingga mampu mendorong untuk belajar sebagai seorang legislator, dimana terjadi transper pengetahuan dan pengalaman untuk mendukung kinerjanya sebagai anggota dewan. Selain itu indicator kemampuan yang tak kalah penting berperan adalah keterampilan atau skill pimpinan partai/dewan dalam meningkatkan perhatian terhadap konsentrasi pekerjaan dan kesempatan pimpinan partai/dewan untuk terus mengarahkan anggota DPRD Kota Banjarmasin tentang tupoksi serta kode etik legislator. Disisi lain yang masih terus diperhatikan dan ditingkatkan adalah kemampuan pengetahuan anggota DPRD Kota Banjarmasin dalam memecahkan persoalan dilapangan dengan volume pekerjaan sesuai dengan target yang telah ditentukan.

Sementara itu motivasi anggota DPRD Kota Banjarmasin meskipun belum berpengaruh dominan terhadap kinerja para legialator memiliki peran sebagai daya dorong yang mampu menggerakkan anggota DPRD untuk giat dan memiliki semangat dalam bekerja sehingga berdampak pada peningkatan kinerja.

Kinerja anggota DPRD Kota Banjarmasin sangat baik ditunjukkan dengan kemampuan anggota dewan dalam mendengar aspirasi masyarakat dan memperjuangkan kepentingan masyarakat (akuntabilitas), kemudian anggota dewan juga mampu mentransformasi berbagai aspirasi dari masyarakat Banjarmasin yang memilihnya (responsivitas).Anggota DPRD Kota Banjarmasin ternyata memiliki kemampuan yang baik dalam melayani masyarakat dengan iklas serta tidak pilih kasih (reliability).

Setelah menguraikan jawaban responden, maka langkah selanjutnya adalah dilakukannya analisi data. Untuk menguji kualitas data penelitian digunakan alat uji validitas dan reabilitas terhadap data. Uji validitas dilakukan untuk menunjukkan kemampuan instrument dari variabel dapat mengungkap data atau informasi dari suatu variabel yang diteliti secara tepat dan mampu mengukur apa yang diinginkan atas penelitian tersebut. Sedangkan uji reabilitas terhadap data dilakukan untuk mengetahui kekonsistenan dan akurasi data yang telah dikumpulkan melalui kuisioner penelitian. Suatu kuisioner dapat dikatakan realibel atau handal, jika jawaban responden terhadap pertanyaan adalah konsisten atau stabil dari waktu ke waktu.

Adapun hasil analisis data yang digunakan dalam penelitian ini sebagai berikut :

\section{Uji Validitas}

Uji Validitas adalah uji statistik yang digunakan untuk menentukan seberapa valid suatu kuesioner yang memuat item-item pernyataan mengukur konstruk atau variabel yang diteliti. Tinggi-rendahnya koefesien validitas menggambarkan kemampuan mengungkap data atau informasi dari variabel yang diteliti.

Penentuan kategori dari validitas instrument yang mengacu pada pengklasifikasian validitas yang dikemukakan oleh Guilford 1956 dalam Arikunto (2003 : 276) adalah sebagai berikut :

$0,80-1,00$ : validitas sangat tinggi (sangat baik). $0,60<0,80$ : validitas tinggi (baik).

$0,40<0,60$ : validitas sedang (cukup). $0,20<0,40$ : validitas rendah (kurang).

$0,00 \leq 0,20$ : validitas sangat rendah (tidak valid).

Uji Validitas Item atau butir dapat pula dilakukan dengan menggunakan software SPSS yang dalam hal ini menggunakan versi 19. Untuk proses ini, akan digunakan Uji Korelasi Pearson Product Moment. Dalam uji ini, setiap item akan diuji relasinya dengan skor total variabel yang dimaksud. Dalam hal ini masing-masing item yang ada di dalam variabel $\mathrm{X}$ dan $\mathrm{Y}$ akan diuji relasinya dengan skor total variabel tersebut.

\section{a. Variabel Kemampuan}

Berdasarkan Dari hasil perhitungan menggunakan Software SPSS versi 19 seperti yang termuat pada lampiran 3, maka dikemukakan indikator yang membentuk konstruk atau variabel kemampuan seperti tampak pada Tabel 16 sebagai berikut :

Tabel

Validitas Indikator Variabel Kemampuan $\left(\mathbf{X}_{1}\right)$

\begin{tabular}{|c|c|c|c|c|c|c|}
\hline No & $\begin{array}{c}\text { Kode } \\
\text { Indikator }\end{array}$ & $\begin{array}{c}\text { Indikator } \\
\text { Variabel }\end{array}$ & $\begin{array}{c}\mathbf{r} \\
\text { hitung }\end{array}$ & $\begin{array}{c}\mathbf{r} \\
\text { tabel }\end{array}$ & Kesimpulan & Validitas \\
\hline \multirow[t]{18}{*}{1.} & $\mathrm{X}_{1.1}$ & Pengetahuan & & & & \\
\hline & & Item 1 & 0,827 & & $r_{\text {hitung }}>r_{\text {table }}$ & Valid \\
\hline & & Item 2 & 0,726 & & $r_{\text {hitung }}>r_{\text {table }}$ & Valid \\
\hline & & Item 3 & 0,658 & & $r_{\text {hitung }}>r_{\text {table }}$ & Valid \\
\hline & & Item 4 & 0,739 & & $r_{\text {hitung }}>r_{\text {table }}$ & Valid \\
\hline & & Item 5 & 0,724 & & $r_{\text {hitung }}>r_{\text {table }}$ & Valid \\
\hline & & Item 6 & 0,358 & & $r_{\text {hitung }}>r_{\text {table }}$ & Valid \\
\hline & & Item 7 & 0,364 & & $r_{\text {hitung }}>r_{\text {table }}$ & Valid \\
\hline & & Item 8 & 0,591 & & $r_{\text {hitung }}>r_{\text {table }}$ & Valid \\
\hline & & Item 9 & 0,326 & 0,243 & $r_{\text {hitung }}>r_{\text {table }}$ & Valid \\
\hline & & Item 10 & 0,845 & & $r_{\text {hitung }}>r_{\text {table }}$ & Valid \\
\hline & & Item 11 & 0,445 & & $r_{\text {hitung }}>r_{\text {table }}$ & Valid \\
\hline & & Item 12 & 0,682 & & $r_{\text {hitung }}>r_{\text {table }}$ & Valid \\
\hline & & Item 13 & 0,834 & & $r_{\text {hitung }}>r_{\text {table }}$ & Valid \\
\hline & & Item 14 & 0,565 & & $r_{\text {hitung }}>r_{\text {table }}$ & Valid \\
\hline & & Item 15 & 0,465 & & $r_{\text {hitung }}>r_{\text {table }}$ & Valid \\
\hline & & Item 16 & 0,433 & & $r_{\text {hitung }}>r_{\text {table }}$ & Valid \\
\hline & & Item 17 & 0,535 & & $r_{\text {hitung }}>r_{\text {table }}$ & Valid \\
\hline
\end{tabular}


Jurnal Riset Inspirasi Manajemen Dan Kewirausahaan Volume 2 No. 1 Edisi Maret 2018

\begin{tabular}{|c|c|c|c|c|c|c|}
\hline No & $\begin{array}{c}\text { Kode } \\
\text { Indikator }\end{array}$ & $\begin{array}{l}\text { Indikator } \\
\text { Variabel }\end{array}$ & $\begin{array}{c}\mathbf{r} \\
\text { hitung }\end{array}$ & $\underset{\text { tabel }}{r}$ & Kesimpulan & Validitas \\
\hline & & Item 18 & 0,636 & & $r_{\text {hitung }}>r_{\text {table }}$ & Valid \\
\hline \multirow[t]{15}{*}{2} & $\mathrm{X}_{1.2}$ & Keterampila & & & & \\
\hline & & Item 19 & 0,389 & \multirow{14}{*}{$\begin{array}{c}0,24 \\
3\end{array}$} & $r_{\text {hitung }}>r_{\text {table }}$ & Valid \\
\hline & & Item 20 & 0,811 & & $r_{\text {hitung }}>r_{\text {table }}$ & Valid \\
\hline & & Item 21 & 0,720 & & $r_{\text {hitung }}>r_{\text {table }}$ & Valid \\
\hline & & Item 22 & 0,750 & & $r_{\text {hitung }}>r_{\text {table }}$ & Valid \\
\hline & & Item 23 & 0,574 & & $r_{\text {hitung }}>r_{\text {table }}$ & Valid \\
\hline & & Item 24 & 0,665 & & $r_{\text {hitung }}>r_{\text {table }}$ & Valid \\
\hline & & Item 25 & 0,602 & & $r_{\text {hitung }}>r_{\text {table }}$ & Valid \\
\hline & & Item 26 & 0,752 & & $r_{\text {hitung }}>r_{\text {table }}$ & Valid \\
\hline & & Item 27 & 0,813 & & $r_{\text {hitung }}>r_{\text {table }}$ & Valid \\
\hline & & Item 28 & 0,631 & & $r_{\text {hitung }}>r_{\text {table }}$ & Valid \\
\hline & & Item 29 & 0,548 & & $r_{\text {hitung }}>r_{\text {table }}$ & Valid \\
\hline & & Item 30 & 0,532 & & $r_{\text {hitung }}>r_{\text {table }}$ & Valid \\
\hline & & Item 31 & 0,604 & & $r_{\text {hitung }}>r_{\text {table }}$ & Valid \\
\hline & & Item 32 & 0,647 & & $r_{\text {hitung }}>r_{\text {table }}$ & Valid \\
\hline
\end{tabular}

Sumber : Hasil Penelitian (data di olah

Dari pengujian validitas diatas, diketahui seluruh butir pada pertanyaan Variabel Kemampuan $\left(\mathrm{X}_{1}\right)$ dinyatakan valid karena $\mathrm{r}_{\text {hitung }}>\mathrm{r}$ table $(0.243)$.

\section{b. Variabel Motivasi}

Berdasarkan Dari hasil perhitungan menggunakan Software SPSS versi 19 seperti yang termuat pada lampiran 3, maka dikemukakan indikator yang membentuk konstruk atau variabel motivasi seperti tampak pada Tabel sebagai berikut

\section{Tabel}

\begin{tabular}{|c|c|c|c|c|c|}
\hline $\begin{array}{c}\text { Kode } \\
\text { Indikator }\end{array}$ & $\begin{array}{c}\text { Indikator } \\
\text { Variabel }\end{array}$ & $\begin{array}{c}\mathbf{r} \\
\text { hitung }\end{array}$ & $\begin{array}{c}r \\
\text { tabel }\end{array}$ & Kesimpulan & Validitas \\
\hline $\mathrm{X}_{2.1}$ & $\begin{array}{l}\text { Motif : } \\
\text { Item } 33 \\
\text { Item } 34 \\
\text { Item } 35 \\
\text { Item } 36 \\
\text { Item } 37 \\
\text { Item } 38 \\
\text { Item } 39 \\
\text { Item } 40\end{array}$ & $\begin{array}{l}0,722 \\
0,809 \\
0,755 \\
0,534 \\
0,615 \\
0,369 \\
0,714 \\
0,554\end{array}$ & 0,243 & $\begin{array}{l}r_{\text {hitung }}>r_{\text {table }} \\
r_{\text {hitung }}>r_{\text {table }} \\
r_{\text {hitung }}>r_{\text {table }} \\
r_{\text {hitung }}>r_{\text {table }} \\
r_{\text {hitung }}>r_{\text {table }} \\
r_{\text {hitung }}>r_{\text {table }} \\
r_{\text {hitung }}>r_{\text {table }} \\
r_{\text {hitung }}>r_{\text {table }}\end{array}$ & $\begin{array}{l}\text { Valid } \\
\text { Valid } \\
\text { Valid } \\
\text { Valid } \\
\text { Valid } \\
\text { Valid } \\
\text { Valid } \\
\text { Valid }\end{array}$ \\
\hline $\mathrm{X}_{2.2}$ & $\begin{array}{l}\text { Harapan: } \\
\text { Item } 41 \\
\text { Item } 42 \\
\text { Item } 43 \\
\text { Item } 44 \\
\text { Item } 45 \\
\text { Item } 46 \\
\text { Item } 47\end{array}$ & $\begin{array}{l}0,687 \\
0,734 \\
0,597 \\
0,853 \\
0,798 \\
0,726 \\
0,752\end{array}$ & 0,243 & $\begin{array}{l}\mathrm{r}_{\text {hitung }}>\mathrm{r}_{\text {table }} \\
\mathrm{r}_{\text {hitung }}>\mathrm{r}_{\text {table }} \\
\mathrm{r}_{\text {hitung }}>\mathrm{r}_{\text {table }} \\
\mathrm{r}_{\text {hitung }}>\mathrm{r}_{\text {table }} \\
\mathrm{r}_{\text {hitung }}>\mathrm{r}_{\text {table }} \\
\mathrm{r}_{\text {hitung }}>\mathrm{r}_{\text {table }} \\
\mathrm{r}_{\text {hitung }}>\mathrm{r}_{\text {table }}\end{array}$ & $\begin{array}{l}\text { Valid } \\
\text { Valid } \\
\text { Valid } \\
\text { Valid } \\
\text { Valid } \\
\text { Valid } \\
\text { Valid }\end{array}$ \\
\hline $\mathrm{X}_{2.3}$ & $\begin{array}{l}\text { Insentif: } \\
\text { Item } 48 \\
\text { Item } 49 \\
\text { Item } 50 \\
\text { Item } 51 \\
\text { Item } 52 \\
\text { Item } 53\end{array}$ & $\begin{array}{l}0,707 \\
0,457 \\
0,581 \\
0,544 \\
0,651 \\
0,670 \\
\end{array}$ & 0,243 & $\begin{array}{l}r_{\text {hitung }}>r_{\text {table }} \\
r_{\text {hitung }}>r_{\text {table }} \\
r_{\text {hitung }}>r_{\text {table }} \\
r_{\text {hitung }}>r_{\text {table }} \\
r_{\text {hitung }}>r_{\text {table }} \\
r_{\text {hitung }}>r_{\text {table }}\end{array}$ & $\begin{array}{l}\text { Valid } \\
\text { Valid } \\
\text { Valid } \\
\text { Valid } \\
\text { Valid } \\
\text { Valid } \\
\end{array}$ \\
\hline
\end{tabular}

Sumber : Hasil Penelitian (data di olah)

\section{c. Variabel Kinerja}

Berdasarkan Dari hasil perhitungan menggunakan Software SPSS versi 19 seperti yang termuat pada lampiran 3, maka dikemukakan indikator yang membentuk konstruk atau variabel Kinerja seperti tampak pada Tabel 18 sebagai berikut :

Tabel 18

Validitas Indikator Variabel Kinerja (Y)

\begin{tabular}{ccccccc}
\hline No. & $\begin{array}{c}\text { Kode } \\
\text { Indikator }\end{array}$ & $\begin{array}{c}\text { Indikator } \\
\text { Variabel }\end{array}$ & $\begin{array}{c}\mathbf{r} \\
\text { hitung }\end{array}$ & $\begin{array}{c}\mathbf{r} \\
\text { tabel }\end{array}$ & Kesimpulan & Validitas \\
\hline 1. & $\mathrm{Y}_{1}$ & Akuntabilitas & & & & \\
& & $\vdots$ & 0,832 & & $\mathrm{r}_{\text {hitung }}>\mathrm{r}_{\text {table }}$ & Valid \\
& & Item 1 & 0,865 & 0,243 & $\mathrm{r}_{\text {hitung }}>\mathrm{r}_{\text {table }}$ & Valid \\
& & Item 2 & 0,610 & & $\mathrm{r}_{\text {hitung }}>\mathrm{r}_{\text {table }}$ & Valid \\
\hline & Item 3 & 0,910 & &
\end{tabular}

\begin{tabular}{|c|c|c|c|c|c|c|}
\hline No. & $\begin{array}{c}\text { Kode } \\
\text { Indikator }\end{array}$ & $\begin{array}{c}\text { Indikator } \\
\text { Variabel }\end{array}$ & $\begin{array}{c}\mathbf{r} \\
\text { hitung }\end{array}$ & $\begin{array}{c}r \\
\text { tabel }\end{array}$ & Kesimpulan & Validitas \\
\hline \multirow[t]{6}{*}{2.} & $\mathrm{Y}_{2}$ & Responsivitas & & \multirow{6}{*}{0,243} & & \\
\hline & & Item 4 & 0,574 & & $r_{\text {hitung }}>r_{\text {table }}$ & Valid \\
\hline & & Item 5 & 0,790 & & $r_{\text {hitung }}>r_{\text {table }}$ & Valid \\
\hline & & Item 6 & 0,858 & & $r_{\text {hitung }}>r_{\text {table }}$ & Valid \\
\hline & & Item 7 & 0,701 & & $r_{\text {hitung }}>r_{\text {table }}$ & Valid \\
\hline & & Item 8 & 0,793 & & $r_{\text {hitung }}>r_{\text {table }}$ & Valid \\
\hline \multirow[t]{4}{*}{3.} & $\mathrm{Y}_{3}$ & Reliability: & & & & \\
\hline & & Item 9 & 0,699 & \multirow{3}{*}{0,243} & $r_{\text {hitung }}>r_{\text {table }}$ & Valid \\
\hline & & Item 10 & 0,745 & & $r_{\text {hitung }}>r_{\text {table }}$ & Valid \\
\hline & & Item 11 & 0,863 & & $r_{\text {hitung }}>r_{\text {table }}$ & Valid \\
\hline
\end{tabular}

Sumber : Hasil Penelitian (data di olah)

Dari pengujian validitas diatas, diketahui seluruh butir pada pertanyaan Variabel Kinerja (Y) dinyatakan valid karena $r_{\text {hitung }}>r_{\text {table }}(0.243)$.

\section{Uji Reliabilitas}

Uji Reliabilitas dilakukan dengan uji Alpha Cronbach.Formula Alpha Cronbach sebagai berikut :

$$
\alpha=\left(\frac{K}{K-1}\right)\left(\frac{s_{r}^{2}-\Sigma s_{i}^{2}}{s_{x}^{2}}\right)
$$

\section{$a \quad=$ Koefisien reliabilitas Alpha Cronbach \\ $K \quad=$ Jumlah item pertany aan yang diuji$$
\Sigma s_{i}^{2} \quad=\text { Jumlah varians skor item }
$$ \\ $S X^{2} \quad=$ Varians skor-skor tes (seluruh item $\mathrm{K}$ )}

Jika nilai alpha >0,6 artinya reliabilitas mencukupi, Jika nilai alpha $>0,7$ artinya reliabilitas lebih dari cukup (sufficient reliability) sementara jika alpha > 0,80 ini mensugestikan seluruh item reliabel dan seluruh tes secara konsisten secara internal karena memiliki reliabilitas yang kuat. Atau ada pula yang memaknakannya sebagai berikut :

1). Jika alpha $>0,90$ maka reliabilitas sempurna

2). Jika alpha antara $0,70-0,90$ maka reliabilitas tinggi

3). Jika alpha antara $0,50-0,70$ maka reliabilitas moderat

4). Jika alpha $<0,50$ maka reliabilitas rendah

Jika alpha rendah, kemungkinan satu atau beberapa item tidak reliabel : Segera identifikasi dengan prosedur analisis per item. Item Analysis adalah kelanjutan dari tes Aplha sebelumnya guna melihat item-item tertentu yang tidak reliabel. Lewat Item analisis ini maka satu atau beberapa item yang tidak reliabel dapat dibuang sehingga Alpha dapat lebih tinggi lagi nilainya.

Reliabilitas item diuji dengan melihat Koefisien Alpha dengan melakukan Reliability Analysis dengan SPSS ver. 19.0 for Windows. Akan dilihat nilai Alpha-Cronbach untuk reliabilitas keseluruhan item dalam satu variabel. Agar lebih teliti, dengan menggunakan SPSS, juga akan dilihat pada reliability statistic pada lampiran.

Reliabilitas menguji konsistensi suatu instrumen dalam mengukur konsep yang harus 
diukur atau melakukan fungsi ukurnya. Instrumen yang reliabel adalah instrumen yang bila digunakan beberapa kali untuk mengukur objek yang sama akan menghasilkan data yang sama (Sugiyono, 1999). Dalam penelitian ini uji reliabilitas dilakukan dengan menghitung Cronbach's Alpha dari masing-masing instrumen dalam suatu variabel. Instrumen yang dipakai dalam variabel dikatakan andal (reliable) bila memiliki Cronbach's alpha lebih dari 0,6(Nunnaly, 1978 dalam Suharsimi Arikunto, 2003).

\section{a. Variabel Kemampuan}

Berdasarkan Dari hasil perhitungan menggunakan Software SPSS versi 19 seperti yang termuat pada lampiran 4, maka dikemukakan reliabilitas indikator yang membentuk konstruk atau variabel kompetensi anggota DPRD seperti tampak pada Tabel sebagai berikut :

\section{Tabel}

Reliabilitas Indikator Variabel Kemampuan $\left(\mathbf{X}_{1}\right)$

\begin{tabular}{cccccc}
\hline No. & $\begin{array}{c}\text { Kode } \\
\text { Indikator }\end{array}$ & $\begin{array}{c}\text { Indikator } \\
\text { Variabel }\end{array}$ & $\begin{array}{c}\alpha \\
\text { Cronbach's }\end{array}$ & $\begin{array}{c}\text { limit } \\
\text { minimum }\end{array}$ & Reliabilitas \\
\hline 1. & $\mathrm{X}_{1.1}$ & Pengetahuan & 0,753 & 0,60 & Reliabel \\
2. & $\mathrm{X}_{1.2}$ & Keterampilan & 0,758 & 0,60 & Reliabel \\
\hline
\end{tabular}

Dari Tabel di atas, diketahui bahwa indikator yang membentuk konstruk atau variabel Kemampuan ialah pengetahuan dengan $\alpha$ Cronbach's 0,753, keterampilan dengan $\alpha$ Cronbach's 0,758.

Selanjutnya dengan membandingkan $\alpha$ Cronbach's dengan limit minimum sebesar 0,60 (Nunnaly, 1978 dalam Suharsimi Arikunto, 2003), maka dapatlah dinyatakan bahwa masing-masing indikator tersebut nilai a Cronbach's nya lebih besar dari pada nilai limit minimum, dengan demikian dapat dinyatakan bahwa indikator pengetahuan, keterampilan, dapat dikatakan reliabel dan ke semua item pernyataan dari kuesioner atau instrument tersebut ialah reliabel.

\section{b. Variabel Motivasi}

Berdasarkan Dari hasil perhitungan menggunakan Software SPSS versi 19 seperti yang termuat pada lampiran 4, maka dikemukakan reliabilitas indikator yang membentuk konstruk atau variabel Motivasiseperti tampak pada Tabel sebagai berikut :

Tabel

Reliabilitas Indikator Variabel Motivasi $\left(\mathbf{X}_{2}\right)$

\begin{tabular}{cclccc}
\hline No. & $\begin{array}{c}\text { Kode } \\
\text { Indikator }\end{array}$ & $\begin{array}{c}\text { Indikator } \\
\text { Variabel }\end{array}$ & $\begin{array}{c}\alpha \\
\text { Cronbach's }\end{array}$ & $\begin{array}{c}\text { limit } \\
\text { minimum }\end{array}$ & Reliabilitas \\
\hline 1. & $\mathrm{X}_{2.1}$ & Motif & 0,747 & 0,60 & Reliabel \\
2. & $\mathrm{X}_{2.2}$ & Harapan & 0,775 & 0,60 & Reliabel \\
3. & $\mathrm{X}_{2.3}$ & Insentif & 0,734 & 0,60 & Reliabel \\
\hline
\end{tabular}

Dari tabel di atas, diketahui bahwa indikator yang membentuk konstruk atau variabel Motivasi ialah motif dengan $\alpha$ Cronbach's 0,747, Harapan dengan $\alpha$ Cronbach's 0,775, Insentif dengan dengan $\alpha$ Cronbach's 0,734

Selanjutnya dengan membandingkan $\alpha$ Cronbach's dengan limit minimum sebesar 0,60 (Nunnaly, 1978 dalam Suharsimi Arikunto, 2003), maka dapatlah dinyatakan bahwa masing-masing indikator tersebut nilai $\alpha$ Cronbach's nya lebih besar dari pada nilai limit minimum, dengan demikian dapat dinyatakan bahwa indikator Motif, Harapan, Insentif dapat dikatakan reliabel dan kesemua item pernyataan dari kuesioner atau instrument tersebut ialah reliabel.

\section{c. Variabel Kinerja}

Berdasarkan Dari hasil perhitungan menggunakan Software SPSS versi 19 seperti yang termuat pada lampiran 4, maka dikemukakan reliabilitas indikator yang membentuk konstruk atau variabel Kinerja seperti tampak pada Tabel sebagai berikut :

Tabel

Reliabilitas Indikator Variabel Kinerja (Y)

\begin{tabular}{cccccc}
\hline No. & $\begin{array}{c}\text { Kode } \\
\text { Indikator }\end{array}$ & $\begin{array}{c}\text { Indikator } \\
\text { Variabel }\end{array}$ & $\begin{array}{c}\alpha \\
\text { Cronbach's }\end{array}$ & $\begin{array}{c}\text { limit } \\
\text { minimum }\end{array}$ & Reliabilitas \\
\hline 1. & $\mathrm{X}_{2.1}$ & Akuntabilitas & 0,819 & 0,60 & Reliabel \\
2. & $\mathrm{X}_{2.2}$ & Responsivitas & 0,791 & 0,60 & Reliabel \\
3. & $\mathrm{X}_{2.3}$ & Reliability & 0,812 & 0,60 & Reliabel \\
\hline
\end{tabular}

Dari Tabel di atas, diketahui bahwa indikator yang membentuk konstruk atau variabel Kinerja ialah Akuntabilitas dengan $\alpha$ Cronbach's 0,819, Responsivitas dengan $\alpha$ Cronbach's 0,791, Reliability dengan dengan $\alpha$ Cronbach's 0,812 .

Selanjutnya dengan membandingkan $\alpha$ Cronbach's dengan limit minimum sebesar 0,60 (Nunnaly, 1978 dalam Suharsimi Arikunto, 2003), maka dapatlah dinyatakan bahwa masing-masing indikator tersebut nilai $\alpha$ Cronbach's nya lebih besar dari pada nilai limit minimum, dengan demikian dapat dinyatakan bahwa indikator akuntabilitas, Responsivitas, Reliabilty dapat dikatakan reliabel dan ke semua item pernyataan dari kuesioner atau instrument tersebut ialah reliabel.

\section{Pengujian Hipothesis Model Regresi}

Berdasarkan hasil analisis Model regresi Kemampuan dan Motivasi terhadap Kinerja, pengujian Hipothesis dapat dilihat pada gambar 8 .

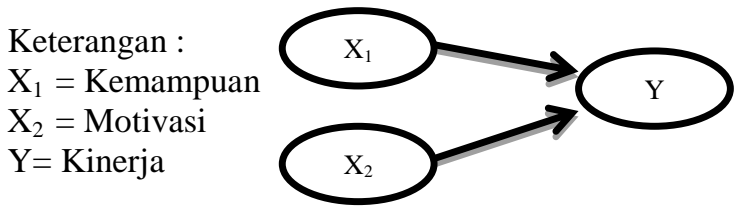

Gambar 8: Model Regresi Antar Variabel $X_{1}, X_{2}$ dan Y 
a. Metode Analisis

Dari Gambar 8 di atas, dapatlah dianalisis pengujian hipotesis dengan menggunakan metode Analisis Regresi Linier. Untuk mengetahui adanya pengaruh antara Kemampuan $\left(\mathrm{X}_{1}\right)$, Motivasi $\left(\mathrm{X}_{2}\right)$ dan Kinerja (Y), digunakan metode analisis regresi secara simultan sebagai berikut :

Hasil Analisis regresi secara simultan

Hasil Uji Kemampuan $\left(\mathrm{X}_{1}\right)$, Motivasi $\left(\mathrm{X}_{2}\right)$ terhadap Kinerja (Y) secara simultan pada Anggota DPRD Banjarmasin. Analisis yang digunakan adalah Regresi Linear dan di uji dengan menggunakan tabel distribusi.

\section{Tabel}

Hasil Analisis Secara Simultan Variabel Kemampuan $\left(\mathbf{X}_{1}\right)$, Motivasi $\left(\mathbf{X}_{2}\right)$ terhadap Kinerja

\begin{tabular}{cccccc}
\hline Simbol & Variabel & Coef. regres & T Hitung & $\begin{array}{c}\text { Korelasi } \\
(\mathbf{r})\end{array}$ & $\begin{array}{c}\text { Diterminasi } \\
\left(\mathbf{r}^{2}\right)\end{array}$ \\
\hline $\mathrm{X}_{1}$ & Kemampuan & 0,177 & $2,914^{*}$ & 0,732 & 0,536 \\
$\mathrm{X}_{2}$ & Motivasi & 0,074 & $0,944^{(\mathrm{ns})}$ & 0,732 & 0,53 \\
\hline
\end{tabular}

Sumber : Hasil Penelitian (data di olah), 2015.

Hipothesis :

Kemampuan \& Motivasi Terhadap Kinerja Anggota DPRD Banjarmasin.

$\mathrm{H}_{0} \quad$; Kemampuan \& Motivasi tidak mempengaruhi Kinerja

$\mathrm{H}_{1} \quad$; Kemampuan \& Motivasi dapat mempengaruhi Kinerja

Y : Kinerja

$\mathrm{X}_{1} \quad$ : Kemampuan

$\mathrm{X}_{2} \quad$ : Motivasi

$\mathrm{Y}=\alpha+\beta \mathrm{X}_{1}+\beta \mathrm{X}_{2}+\mathrm{e}_{\mathrm{i}}$

$Y=19,203+0,177 X_{1}+0,074 X_{2}+\varepsilon_{i}$

$\mathrm{s} \quad 0,570 \quad 0,184$

t $2,914^{*} \quad 0,944^{(\mathrm{ns})}$

$\mathrm{t}_{(45 ; 0.05)}=1.679 \mathrm{R}=0,732 \quad \mathrm{R}^{2}=0,536$

Berdasarkan uji t secara simultan diketahui bahwa untuk Kemampuan $\mathrm{t}_{\text {hitung }}=2,914^{*}>\mathrm{t}_{(45 ; 0.05)}$ $=1.679$ adalah signifikan dan untuk Motivasi $\mathrm{t}_{\text {hitung }}$ $=0,944^{\mathrm{ns}}<\mathrm{t}_{(45 ; 0.05)}=1.679$, maka $\mathrm{H}_{0}$ ditolak dan $\mathrm{H}_{1}$ diterima. Artinya Secara Simultan Kemampuan dan Motivasi dapat mempengaruhi Kinerja walaupun terdapat variabel Motivasi yang tidak dapat mempengaruhi Kinerja, dapat disimpulkan pula bahwa variabel kemampuan mempunyai pengaruh yang paling dominan, hal ini ditunjukkan oleh nilai $\mathrm{t}_{\text {hitung }}=2,914^{*}$ (signifikan) dibandingkan dengan variabel motivasi $\mathrm{t}_{\text {hitung }}=0,944^{\mathrm{ns}}$.

Selanjutnya berdasarkan analisis data di atas, dapat diketahui terdapat hubungan yang kuat (di mana koefisien korelasi atau $\mathrm{R}=0,732$ ) antara Kemampuan \& Motivasi terhadap Kinerja. Artinya jika Kemampuan dan Motivasi tersebut diperbanyak $1 \%$ saja, maka Kinerja akan meningkat sebesar 0,177\% untuk Kemampuan dan 0,074\% untuk Motivasi.
Selanjutnya jika dilihat dari data koefisien diterminasi $\left(\mathrm{R}^{2}\right)=0,536$ artinya terdapat sebanyak $53,6 \%$ Secara Simultan Kemampuan \& Motivasimempengaruhi Kinerja tersebut, dan sisanya $46,4 \%$ Kinerja tersebut dipengaruhi oleh faktor lain.

\section{PENUTUP}

Kesimpulan yang diperoleh dari hasil penelitian ini dapat dikemukakan bahwa secara simultan kemampuan kerja berpengaruh secara signifikan terhadap kinerja anggota DPRD Kota Banjarmasin, sedangkan motivasi kerja non signifikan, artinya kemampuan dan motivasi dapat mempengaruhi kinerja walaupun terdapat variabel motivasi yang tidak dapat mempengaruhi kinerja anggota DPRD Kota Banjarmasin.

Kemampuan kerja merupakan variabel yang berpengaruh dominan terhadap kinerja anggota DPRD Kota Banjarmasin, karena berdasarkan hasil uji kemampuan, motivasi terhadap kinerja secara simultan pada anggota DPRD Kota Banjarmasin, diketahui bahwa variabel kemampuan mempunyai pengaruh paling dominan, dibandingkan dengan variabel motivasi.

Temuan penting dalam penelitian ini adalah bahwa anggota DPRD Kota Banjarmasin dalam mengenali lingkungan rekan kerja sebagai metode pembelajaran sebagai legislator terbukti mampu meningkatkan akuntabilitas sebagai legislator, hal ini terbukti dimana anggota DPRD Kota Banjarmasin mampu serta bersedia sebagai pendengar aspirasi masyarakat dan mampu juga memperjuangkan kepentingan masyarakat di Kota Banjarmasin.

\section{DAFTAR PUSTAKA}

Arikunto. 2006. Instrumen Penelitian. Jakarta.

Arikunto, Suharsimi, 2003, Manajemen Penelitian. Jakarta , PT. Rineka Cipta.

Danang Sunyoto, 2013, Perilaku Organisasional (Teori, Kuesioner dan Proses Analisis Data), CAPS (Center of Academic Publising Service), Yogyakarta.

Darma, Jufri. 2012. Pengaruh Pengetahuan Anggota Dewan tentang Anggaran terhadap Pengawasan Keuangan Daerah dengan Partisipasi Masyarakat sebagai Variabel Moderating. Jurnal Mediasi, Vol. 4 , Juni 2012.

Gibson, James I. 1989, Manajemen dan Perilaku Keorganisasian, dalam http:// gilangdawous.files.wordpress.com/2011/ 09/jadi-buku.docx.

Gitosudarmo, Indriyo \& Sudita, I Nyoman (2000), Perilaku Keorganisasian, Edisi 1, Yogyakarta: BPFE. 
Gregory Moorhead dan Ricky W. Griffin, 2010, Perilaku Organisasi Manajemen Sumber Daya Manusia dan Organisasi edisi 9, Salemba Empat, Jakarta.

Guritno, Bambang dan Waridin. 2005. Pengaruh Persepsi Karyawan Mengenai Perilaku Kepemimpinan, Kepuasan Kerja Dan Motivasi Terhadap Kinerja. JRBI.Vol 1. No 1.

Hersey dan Blanchard, 1993.Teori Situasional Kepemimpinan,Manajemen perilaku organisasi memanfaatkan manusia sumber daya (8th. ed.). Englewood Cliffs. NJ: Prentice-Hall.

Labay, Ilyas, Sujianto dan Zulkarnain. 2012, Kompetensi Pengetahuan, keterampilan, Motivasi Kerja dan Kinerja Anggota DPRD Provinsi Riau.

Malayu S.P. Hasibuan, 2013, Manajemen Sumber Daya Manusia (edisi Revisi), Bumi Aksara, Jakarta.

Merdeka Malang, Universitas. 2014. Pedoman Penulisan dan Ujian Tesis, Program Pasca Sarjana Univeritas Merdeka Malang. Malang.

Moh As'ad. 2003. Psikologi Industri. Yogyakarta: Libery.

Nenny Anggraeni, Pengaruh Kemampuan dan Motivasi terhadap Kinerja Pegawai Pada Sekolah Tinggi Seni Indonesia Bandung,ISSN 1412-565X.

Prabu Mangkunegaran, Anwar. 2009. Manajemen Sumber Daya Manusia Perusahaan. PT Remaja Rosdakarya. Bandung.

Prabu Mangkunegaran, Anwar, 2005. Evaluasi Kinerja. Bandung : Refika.

Riduan, 2009, Skala Pengukuran Variabel-variabel Penelitian, Alfabeta, Bandung.

Rivai, Veithzal dan Basri. 2005. Performance Appraisal: Sistem Yang Tepat Untuk Menilai Kinerja Karyawan Dan Meningkatkan Daya Saing Perusahaan. Rajagrafindo Persada. Jakarta.

Sanusi, Anwar. 2014. Metodologi Penelitian Bisnis disertai contoh Proposal Penelitian Bidang Ilmu Ekonomi dan Manajemen. Penerbit Salemba Empat, Jakarta.

S. Ruky, Achmad. 2004. Sistem Manajemen Kinerja (Performonce Management System). PT. Gramedia Pustaka Utama. Jakarta.

Sedarmayanti, 2014.Manajemen Sumber Daya Manusia , Reformasi Birokrasi dan Manajemen PNS. PT. Refika Aditama, Bandung.

Simamora, Henry, 1997. Manajemen Sumber Daya Manusia. Edisi Kedua.STIE : YKPN

Sisworini dalam Gibson, James L et al 2006. @Organization (Behavior, Struktur,
Processes)". Twelfth Edition, McGrow Hill.

Sulistiyani, Ambar T. dan Rosidah. 2003. Manajemen Sumber Daya Manusia. Graha Ilmu: Yogyakarta.

Sugiyono. 1999. Metode Deskriptif. Jakarta.

Tika, P. 2006. Budaya Organisasi Dan Peningkatan Kinerja Perusahaan. PT Bumi Aksara. Jakarta.

Trihendradi, C. 2013. Step by Step IBM SPSS 21 : Analisis Data Statistik. Andi Offset. Yogyakarta.

Wirawan, 2009, Evaluasi Kinerja Sumber Daya Manusia, Teori, Aplikasi dan Penelitian. Salemba Empat. Jakarta.

Wirawan, 2013, Kepemimpinan, Teori, Psikologi,Perilaku Organisasi, Aplikasi dan Penelitian, Rajawali Pers, Jakarta.

http://www.radarbanjarmasin.co.id/index.php/banu a2/banjarmasin/2105-kinerja-dewandalam-periode-lima-tahun.

http://wahyutriwalodi.blogspot.com/2012/05/Teori Motivasi-kinerja.html, diunduh pada tanggal 26 Nopember 2014 